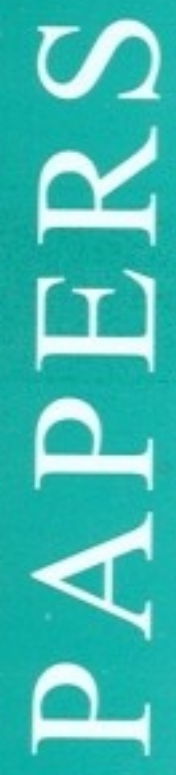

\title{
On Measuring the Complexity of Urban Living
}

\author{
Lubna Hasan
}


PIDE Working Papers

2008:46

\title{
On Measuring the Complexity of Urban Living
}

\author{
Lubna Hasan \\ Pakistan Institute of Development Economics, Islamabad
}

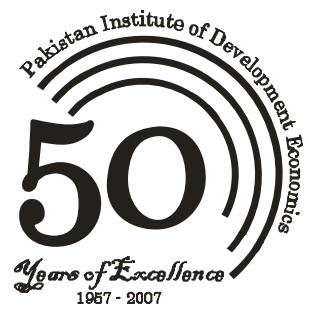

PAKISTAN INSTITUTE OF DEVELOPMENT ECONOMICS ISLAMABAD 
All rights reserved. No part of this publication may be reproduced, stored in a retrieval system or transmitted in any form or by any means-electronic, mechanical, photocopying, recording or otherwise - without prior permission of the author(s) and or the Pakistan Institute of Development Economics, P. O. Box 1091, Islamabad 44000.

\section{(c) Pakistan Institute of Development}

Economics, 2008.

Pakistan Institute of Development Economics Islamabad, Pakistan

E-mail: publications@pide.org.pk

Website: http://www.pide.org.pk

Fax: $\quad$ +92-51-9210886

Designed, composed, and finished at the Publications Division, PIDE. 


\section{O N T E N T S}

Page

Abstract $\quad$ v

1. Introduction 1

2. Ranking Places and Urban Life 2

3. Methodological Issues in City Rankings 4

4. Major City Ranking Initiatives 10

5. Pakistani Cities in the International Perspective 20

6. Conclusion and Recommendations 23

$\begin{array}{lr}\text { Appendix } & 26\end{array}$

$\begin{array}{ll}\text { References } & 27\end{array}$

\section{$1 \quad$ List of Tables}

Table 1. QoL Factors Used to Assess Key City Rankings 8

Table 2. Summary of Dimensions Used in QoL Studies 9

Table 3. Items Considered Most Important in People's Lives 10

Table 4. UN-HABITAT GUIP List of Indicators 11

Table 5. Calculation of CDI by UN-HABITAT GUIP 12

Table 6. Calculation of CDI by ADB CDB 14

Table 7. Weights of EIU Cost-of-living Index 17

Table 8. Weights of EIU QoL Index 18

Table 9. Mercer Cost-of-living Index 23

Appendix Table A1. Dimensions of CDI as measured by ADB 26

\section{$2 \quad$ List of Figures}

Figure 1. City Development Index 21

Figure 2. Ranking and World Cities by GUO City Development Index

Figure 3. Connectivity Index 22

Figure 4. Congestion Index 22 


\begin{abstract}
This paper explores the concept of city ranking as a way to measure the dynamics and complexities of urban life. These rankings have various dimensions and uses. Both the context in which these rankings are done and their nature have changed considerably over time. These rankings face many methodological and measurement problems. A review of major city rankings and the related literature is carried out to suggest a framework for the ranking of Pakistani cities.
\end{abstract}

JEL classification: R12, O18, R23

Keywords: Quality of Life, Cities, Urbanisation 
"Since the sources of the new economic growth are so various and finally perhaps so fickle, the possibilities are endless. It is no accident that, as never before, ranking of cites dominates the media”. [Hall (1995)]

“...you cannot properly measure what you don't understand; and you cannot improve what you don't measure”. [Peter Newton in ADB (2001)]

\section{INTRODUCTION}

Cities have acquired a phenomenally important role in today's world. From being "isolated seats of power from where to govern rural holdings," cities have become the ultimate abode of humanity, and human beings are now a predominantly city dwelling species. Today every second person inhabiting the world is an urban dweller. ${ }^{1}$ The trend is not going to change in the near future as the urban population is expected to grow at double the rate of growth of total world population during 2005-2030 [UNCHS (2007)].

This has encouraged efforts at measuring the diversity of urban life and of cities as such. ${ }^{2}$ Generally dubbed as 'city rankings' or 'city ratings', these exercises are aimed at measuring and comparing cities on a variety of aspects- quality of life (QoL), cost of living, business climate/opportunities, and other criteria. These rankings are done by popular magazines, business consulting firms, international agencies, and academic institutions, and attract a great deal of media and public attention. In particular, QoL comparisons among areas interest residents, business persons, politicians, and policy-makers as evidence compiles in favour of a link between area amenities and the location decisions of households and firms [Blomquist, et al. (1988)].

Acknowledgements: The author wishes to thank Dr Nadeem Ul Haque for his encouragement in writing this paper. Thanks are also due to Dr Musleh-ud Din and Dr G. M. Arif, who provided incisive comments on an earlier draft of this paper. The author also wishes to thank seminar participants at the Pakistan Institute of Development Economics, Islamabad, as well as participants of the "Cities Conference", Karachi (2007), for their valuable comments. An earlier version of this paper titled 'On Ranking Cities: Issues and Options" was published in Haque and Nayab (2007). The usual disclaimer applies.

${ }^{1}$ In 2005, 3.17 billion out of the total world population (6.45 billion) lived in cities [UNCHS (2007)].

${ }^{2}$ The 'diversity' of urban life, and why it is being measured, is discussed below. Also see Nayab (2007) for the role of cities in human life. 
The reduction of complexity of urban living to a single number is appealing to politicians and media alike. For the media, it becomes an interesting headline; for politicians, a political motive-if their constituency ranks low on the QoL index, it can be used to demand higher development expenditure from the state on the pretext of initiating new programmes that will "enhance local quality of life" [Rogerson (1999)].

This paper discusses city rankings as follows. It introduces the concept, discusses the context in which these rankings are done, and then reviews measurement issues in indicators. The paper also outlines a number of major initiatives in ranking cities and discusses current efforts to measure Pakistani cities. Finally, it puts forward suggestions for moving forward.

\section{RANKING PLACES AND URBAN LIFE}

Cities are considered desirable places in which to live. Cities are the "super markets for employment, incubator of technology, suppliers of social services and shelter, portals to the rest of the world, processors of agriculture produce, adders of manufactured value, places to make money through trade, industry, finance, real state" [UNCHS (2001), p. 7]. They are the nexus of commerce and gateways to the world (ibid).

Cities are also the engines of growth-most wealth creation takes place within their bounds. They also offer higher income levels than the national average. Per capita income in African cities is 65 percent higher than the national average [Overman and Venables (2005)]. Productivity is also far higher in cities: Lima houses less than 30 percent of Peru's population but adds 40 percent to the national GDP [UNCHS (2001)]. The evidence suggests that labour productivity increases with city size [Sveikauskas (1975)]. Cities offer many amenities and agglomeration economies ${ }^{3}$ that motivate firms and industries to locate there, with the result that most jobs are created in cities. Cities are also hubs of innovative activities. "The cramming of individuals, occupations, and industries into close quarters provides an environment in which ideas flow quickly from person to person" [Glaeser, et al. (1992), p. 1127]. As such cities act as a nursery for new products and processes [Overman and Venables (2005); Duranton and Puga (2001)].

The reality of city life is a mixture of diverse experiences, however. Cities offer many amenities that make urban living a pleasant experience. City dwellers have many privileges that residents of rural areas are deprived of-

\footnotetext{
${ }^{3}$ Agglomeration economies are positive externalities arising out of a concentration of population and economic activity in one region: provision of pure public and club goods, e.g., roads, medical facilities, health clubs, recreational facilities (cinemas and parks); a wider variety of the aforementioned services; a more complete occupational structure (which gives greater flexibility with respect to the skill and time requirement of a job); chances of upward mobility; and greater personal freedom, etc.
} 
provision of public and club goods e.g., roads, medical facilities, health clubs, recreational facilities (cinemas, parks), cultural activities; a wider variety of aforementioned services; a thick goods market; a more complete occupational structure offering greater flexibility with respect to skill and time requirement of job; chances of upward mobility; and greater personal freedom etc.

City life is not without costs, however. City dwellers have to face the ill effects of congestion, pollution (air, water, and noise), long and stressful commutes [Clark, Kahn and Ofek (1988)]. Cities are also hubs of crimes, conflicts, riots, social unrest. All these constitute disamenities for urban residents. Urban living is, therefore, influenced by the trade offs between positive city effects and negative urban loads. ${ }^{4}$ City ranking studies of the early Seventies were designed to capture these diverse area attributes and study their links with urbanisation and migration trends and the quality of life of urban residents.

Beginning 1990s, these ranking exercises received a considerable make over. Initially developed to measure QoL differences across metropolitan areas and to assess their link with the location decisions of firms and individuals, these rankings have assumed more dimensions over time. Now, they are used as a promotional tool for city marketing ("to put the area on the map") to attract businesses and residents. The onset of globalisation has changed the context within which development takes place. It has considerably altered the geography of capital (both physical and human). The ability of transnational corporations to relocate their operations across the globe has placed cities in a new set of relations with capital, where capital is highly mobile and the relative position of cities much weaker [Rogerson (1999)]. The increased "fluidity of capital" has enhanced the relevance of city rankings as cities try to create a niche for themselves in this competitive environment by offering a "new set of local place attributes"- the QoL being one such factor. "Cities tend to market themselves rather like competing consumer goods... city administrations find themselves impelled to establish some unique quality for their city, some magic ingredient that no other city can precisely match" [Hall (1995), p. 13]. It is in this context of vigorous efforts by urban mangers to "place their area on the map" and make it look more competitive that the roots of recent (popular) city rankings are located.

Recent research also suggests that places attract human capital and talent by offering a range of lifestyle amenities. Individuals with high levels of human capital are economically more mobile and have more options in their location decisions. Cities offering more lifestyle opportunities draw such talent to themselves [Florida (2002)]. Glaeser, Kolko, and Saiz (2001) write that high human capital workers

${ }^{4}$ Cicerchia (1999) qualifies positive city effect as 'access to superior urban functions, opportunities and services', while urban load refers to congestions and environmental degradation [cited in McCrea, et al. (2006)]. 
increase the productivity of a region; at the same time, high human capital areas are pleasant places to live in. Cities must attract workers on the basis of QoL if they are to remain strong. Urban amenities are crucial factors that determine urban viability and growth. Shapiro (2006) contends that improvement in QoL accounts for 40 percent of employment growth for college graduates in US metropolitan areas. City rankings are used to attract human capital and "consumer power"-consumers with money-into the region [Rogerson (1999)].

These rankings are often used as a political tool as well. The European Union, for example, considers “the improvement of QoL” as a principal objective in its general framework of sustainable development. The Committee of the Regions (1999) recommended setting up a "system of local and regional indicators of quality of life to inform policy-makers," to monitor the economic and social progress of member countries ${ }^{5}$ [Biagi, et al. (2006)]. Greenberg (2000) writes that during the hay days of interurban competition in the 1980s and 1990s... 'Quality of Life' became the rallying cry of many big-city mayors...” [cited in Jensen (2005), p. 4]. Despite their widespread use, measures of well-being are afflicted with a host of methodological issues. Langlois and Anderson (2002) write that "the literature has been plagued by conceptual diversity, measurement differences, and the absence of theoretical underpinnings" [Langlois and Anderson (2002), p. 501]. We discuss these issues in the next section.

\section{METHODOLOGICAL ISSUES IN CITY RANKINGS}

Measurement of complex dynamics of urban life and human well-being has an extensive history. ${ }^{6}$ For long, GDP was considered as the sole measure of well-being. During the second half of the twentieth century, dissatisfaction with this measure mounted, and led to the search for a better metric [Ram (1982)]. ${ }^{7}$ The focus shifted to the extension of this approach to include basic needs (health and education) of human life. Many indices were constructed that covered the shortcomings of the earlier approach. The physical quality of life index (PQLI) developed by Morris (1979) included life expectancy at age 1, infant mortality rate, and literacy rate [cited in Slottje (1991)]. The human development index (HDI) of the United Nations is another endeavour for a better, more comprehensive measure of well-being, which included longevity, knowledge and income as its components. ${ }^{8}$

\footnotetext{
${ }^{5}$ See also Fahey, Nolan, and Whelan (2003).

${ }^{6}$ In particular, city rankings have been around for almost three and half decades. Ham, et al. (2004) write that the idea of rating places is not new and the earliest effort to rank areas goes as far back to 17th century America when places with plentiful game, heavier livestock supply, and low probability of death from Indian attacks were considered more "livable".

${ }^{7}$ This is cited in Slottje (1991).

${ }^{8}$ See Booysen (2002) for a review of composite indices of development. Lijn (n.d.) has also compared a modified HDI and PQLI for 133 countries.
} 
The term 'quality of life' was also coined to offset dissatisfaction with a single dimension variable (per capita GDP) as a measure of wellbeing [Rahman, Mittelhammer, and Wandschneider (2003); Cobb (2000); Crafts (1997)], and included factors such as housing, public safety, climate, health and education [Lanteigne (2005) and Slottje (1991)]. The basic premise of this research was that 'good life' depended on a wider range of goods and services than mere income, and was aided by the social indicators movement of the seventies. Sen has added another dimension to well-being research by arguing that quality of life did not depend merely on opportunities, and was determined by human capabilities as well. ${ }^{9}$ Nussbaum and Sen have stressed the need to go beyond the economic measures to include social, political, environmental, and personal dimensions. Dasgupta also argues for an extension of this approach to include civil and political liberties [Cobbs (2000)]. Earlier Dasgupta and Weale had included such measures in their estimation of quality of life in poor countries [ibid].

The studies measuring civic quality have gone through many more transformations over the years. The earliest studies measured 'quality of life' (QoL) differences across metropolitan areas and its link with the location decisions of households and firms [Luger (1996)]. While, in the initial years (late Sixties and early Seventies), the studies on QoL used 'objective' data (literacy rates, infant mortality rates, life expectancy etc.), in the late Seventies the focus shifted to the 'subjective' measures of wellbeing, which relied on an individual's perception about his life [Costanza, Farley, and Templet (2002)]. Since different individuals have different life experiences in a given environment, it was deemed important to ask them how they viewed their life [Veenhoven (2004)]. ${ }^{10}$ However, these studies were confined to academic circles only [Rogerson (1999)].

These ratings caught popular attention with the publication of the Places Rated Almanac. This study by Bayer and Savageau was US based and ranked 354 metropolitan areas on the basis of various QoL factors - cost of living, job outlook, transportation, education, healthcare, crime, art, recreation, and climate - that characterised the livability of a place [cited in Ham, et al. (2004)]. Interest in popular city ratings has surged in recent years. Popular magazines [the Economist, Asia Week, and The Fortune Magazine], business consulting firms [Mercer Human Resource Consulting, Cushman and Wakefield, USB], international development organisations [United Nations Development Programme (UNDP), Asian Development Bank (ADB)] and national governments now carry out city rankings on a regular basis.

${ }^{9}$ Cobb (2000) summarises Sen's argument as: “QoL derives from states of being and opportunities for doing... Without capabilities associated with being (such as health, social connections, and self-esteem) and doing (political activity, intellectual challenges, and engaging work) a person is not able to take advantage of the benefits... [Cobb (2000), p. 10].

${ }^{10}$ The issues of definition and measurement of QoL, objective and subjective indicators will be dealt with later in the paper. 
Though, cities are ranked according to many attributes-QoL, Cost-ofliving, business competitiveness, and composite city performance indicators (e.g., city development index of habitat)—-the QoL index is the most commonly used. Despite its widespread use, QoL studies face many challenges. Indeed, "the measurement and interpretation of measures of the quality of life have been rather elusive” [Naude, Rossouw, and Krugell (2006), p. 6]. The first issue deals with the definition. What actually is meant by the term QoL? Consensus over the definition is limited, and a host of terminologies (well-being, happiness, life satisfaction etc.) are used causing ambiguity [Bramston, et al. (2002)]. Liu (1976) writes, "there are as many quality of life definitions as there are people" [cited in Wish (1986), p. 94]. Schuessler and Fisher state that "the concept lacks specificity; it has as many meanings as life has aspects" [cited in Costanza, Farley, and Templet (2002)]. To get a flavour of the ambiguity and vagueness surrounding the concept, consider the definitions put forth by various authors in Box (1). In essence, the QoL is a multidimensional concept, encompassing distinct domains of life (personal as well as material, social, political and environmental).

\section{Box 1. The Various Shades of the Term 'Quality of Life'}

The best way of approaching quality of life measurement is to measure the extent to which people's 'happiness requirements' are met-i.e., those requirements which are a necessary (although not sufficient) condition of anyone's happiness - those 'without which no member of the human race can be happy.'

McCall, S. (1975) 'Quality of Life'. Social Indicators Research 2: 229-248

Quality of life to a greater or lesser extent consists of two basic ingredients, an operational or environmental and a psychological milieu... These two aspects, the psychological and environmental, need to be considered simultaneously in operationalising the quality of life.

Wish, N. B. (1986) Are We Really Measuring the QoL? Well-being Has Subjective Dimensions, as well as Objective Ones. American Journal of Economics and Sociology 45: January, 93-99.

A multidimensional evaluation of an individual's current life circumstances in the context of the culture in which they live and the values they hold. QoL is primarily a subjective sense of well-being encompassing physical, psychological, social, spiritual dimensions. In some circumstances, objective indicators may supplement or serve as a proxy assessment of QoL.

Haas (1999) A Multidisciplinary Concept Analysis of Quality of Life. West Journal of Nursing Research 21:6, 728-743.

QoL comprised the possession of resources necessary to the satisfaction of individual needs, wants and desires, participation in activities enabling personal development and selfactualisation and satisfactory comparison between oneself and others

Holmes, S. (2004) Assessing the Quality of Life: Reality or Impossible Dream. International Journal of Nursing Studies 42:4, 493-501.

There are essentially two perspectives taken in quality of life research: social indicators research which considers the elites' valuation of what the people need, and conventional quality of life research which studies what people want, in order to improve their quality of life.

- Quality of Life, Ramkrishna Mukherjee, Sage Publications, 1989 
The second issue concerns the type of indicator to be used. There is persistent debate in QoL research about the merits and demerits of the objective approach vis-à-vis the subjective approach [see Veenhoven (2004); Rahman, Mittelhammer, and Wandschneider (2003); Costanza, Farley, and Templet (2002); Cobb (2000); Diener, and Suh (1997); Wish (1986)]. ${ }^{11}$ Objective QoL indicators are based on attributes that can be measured, for example, by per capita income, unemployment, literacy rate, infant mortality rate, and pollution levels. These indicators are mostly based on registration based indices. ${ }^{12}$ The best known indicator is the Human Development Index (HDI) developed by the United Nations Development Programme (UNDP). These objective indicators of quality are only proxies, i.e., they are indirect measures of true conditions (QoL) that researchers try to evaluate [Cobb (2000)]. It is assumed that the objective circumstances influence satisfaction within specific life domains [McCrea, Shyy, and Stimson (2006)].

QoL indicators can also be subjective, i.e., based on people's perceptions of their happiness and satisfaction with living conditions. These indicators are survey based, and directly enquire individuals about their satisfaction with life. Examples are the New Zealand QoL reporting system and the Australian unity well-being index. "Objective measurement is based on explicit criteria and performed by external observer. Subjective measurement involves self reports based on implicit criteria" [Veenhoven (2004), p. 1].

An increasing number of researchers are advocating a third type of indicator, which combines quantitative data (objective approach) with qualitative data (subjective approach) [Wish (1986); Diener and Suh (1997); Veenhoven (2004)]. ${ }^{13}$ Rogerson (1997) conceptualises this approach by defining an environmental quality of life, which comprises both material and personal arenas of life [cited in Turksever and Atalik (2001)]. The link between objective (quantitative) and subjective (qualitative) indices has also been studied [McCrea, et al. (2006); Langlois and Anderson (2002); Diener and Suh (1997)].

Since QoL is a multi dimensional concept (see Box 1), another issue in the construction of the index is to decide which dimensions of life to include. A human life has many domains-economic, political, social, and environmental. Each of these domains can be captured by a number of alternative indicators. For example, social environment, which is one domain of living environment, can be captured by the safety it provides, for the freedom it grants, or the degree of fairness (equity) it allows [Veenhoven (2004)]. The economic aspect can be

\footnotetext{
${ }^{11}$ Also see Shackman, Liu, and Wang (2005) for the review of this issue and availability of data (for measuring QoL) in the public domain

${ }^{12}$ For example, birth and death registration, registration at unemployment bureaus etc.

${ }^{13}$ Rogerson (1997) adopted this approach in measuring QoL in British counties [cited in Turksever and Atalik (2001)]. Turksever and Atalik (2001) have also used this approach in estimating QoL in metropolitan areas of Istanbul, Turkey [ibid)].
} 
captured by the city product, per capita income, household income, employment/unemployment levels etc. A look at Table 1 shows diverse factors included in QoL studies.

Table 1

QoL Factors Used to Assess Key City Rankings

\begin{tabular}{|c|c|c|c|c|c|c|c|}
\hline & Smith & Liu & $\begin{array}{l}\text { Boyer and } \\
\text { Savageau }\end{array}$ & $\begin{array}{l}\text { Rogerson, } \\
\text { et al. }\end{array}$ & Burnley & $\begin{array}{l}\text { Hart, } \\
\text { et al. }\end{array}$ & PCC \\
\hline QoL Factor & 1973 & 1976 & 1981 & 1988 & 1988 & 1989 & 1990 \\
\hline Environment/Pollution & & $\mathrm{X}$ & $\mathrm{X}$ & $\mathrm{X}$ & $\bar{X}$ & & $\bar{X}$ \\
\hline $\begin{array}{l}\text { Atmosphere/Peace and } \\
\text { Quiet }\end{array}$ & & & & & $\mathrm{X}$ & $\mathrm{X}$ & $\mathrm{X}$ \\
\hline Climate & & & $\mathrm{X}$ & $\mathrm{X}$ & X & & \\
\hline Lifestyle Opportunities & & & & & $\mathrm{X}$ & & \\
\hline Employment & & & & $\mathrm{X}$ & $\mathrm{X}$ & & \\
\hline Retirement & & & & & $\mathrm{X}$ & & \\
\hline Housing Costs and Access & $\mathrm{X}$ & $\mathrm{X}$ & $\mathrm{X}$ & $\mathrm{X}$ & & $\mathrm{X}$ & $\mathrm{X}$ \\
\hline Healthcare/Public Health & $\mathrm{X}$ & $\mathrm{X}$ & $\mathrm{X}$ & $\mathrm{X}$ & & $\mathrm{X}$ & $\mathrm{X}$ \\
\hline Crime/Public Safety & $\mathrm{X}$ & & $\mathrm{X}$ & $\mathrm{X}$ & & & $\mathrm{X}$ \\
\hline Transport/Traffic Flow & $\mathrm{X}$ & & & $\mathrm{X}$ & & $\mathrm{X}$ & $\mathrm{X}$ \\
\hline Education & $\mathrm{X}$ & & $\mathrm{X}$ & $\mathrm{X}$ & & $\mathrm{X}$ & $\mathrm{X}$ \\
\hline Provision/Levels & & & & & & & \\
\hline Recreation & & & $\mathrm{X}$ & $\mathrm{X}$ & & & \\
\hline $\begin{array}{l}\text { Economy/Business } \\
\text { Climate }\end{array}$ & $\mathrm{X}$ & $\mathrm{X}$ & & & & $\mathrm{X}$ & \\
\hline Arts/Cultural Diversity & $\mathrm{X}$ & & $\mathrm{X}$ & $\mathrm{X}$ & & $\mathrm{X}$ & \\
\hline $\begin{array}{l}\text { State Taxes/Development } \\
\text { Aid }\end{array}$ & & & & & & $\mathrm{X}$ & \\
\hline Commercial Space & & & & & & $\mathrm{X}$ & \\
\hline Proximity to & & & & & & $\mathrm{X}$ & \\
\hline Suppliers/Market & & & & & & & \\
\hline Food Costs/Cost-of-living & & & $\mathrm{X}$ & $\mathrm{X}$ & & & \\
\hline Political Environment & $\mathrm{X}$ & $\mathrm{X}$ & & & & & \\
\hline Wages & & & & $\mathrm{X}$ & & $\mathrm{X}$ & \\
\hline
\end{tabular}

Source: Rogerson (1999).

One weakness of Quality of Life studies is their ad hoc nature [Biagi, et al. (2006); Cobb (2000); Diener and Suh (1997); Luger (1996)]. The lack of a clear definition and absence of theoretical underpinning has made operationlisation of the concept extremely vague. The choice of indicators used in each study is dictated by factors such as data availability, aims of study and personal choice of researchers [Biagi, et al. (2006) and Lanteigne (2005)]. Further, Luger (1996) contends that one limitation due to ad hoc nature of "livability comparisons" is that they make no effort to link inputs (e.g., education expenditure) with output (literacy rate).

While QoL studies are criticised for being a theoretic and ad hoc, consensus is emerging around a group of indicators (economic opportunities, 
physical environment, climate, pollution, crime, health and education) capturing various domains of life [Rogerson (1999)]. Wish (1986) writes, "forming a consensus on the conceptual definition for 'Quality of Life' is not a major problem... they all include a situation or condition that is perceived by an area's residents and translated by them into varying degrees of a sense of well-being” [Wish (1986), p. 95]. Lanteigne (2005) surveyed the QoL studies conducted during 1996 to 2004. She comes up to the conclusion that a consensus has emerged around the dimensions that are generally used in such studies. Table 2 summarises these dimensions. It is clear that the economy, environment, social, safety, education and health are included in majority of the studies, while housing, urban amenities and transportation are also important indicators of the quality of life.

Table 2

Summary of Dimensions Used in QoL Studies

\begin{tabular}{lc}
\hline Dimension & \% of Studies Using the Dimension \\
\hline Economy & 59 \\
Environment & 59 \\
Social & 59 \\
Safety & 53 \\
Education & 53 \\
Health & 47 \\
Housing & 41 \\
Amenities & 35 \\
Transportation & 35 \\
Infrastructure & 24 \\
Density & 12 \\
Climate & 6 \\
\hline
\end{tabular}

Source: Lanteigne (2005).

But QoL indicators used in city marketing represent a shift in conceptualisation because they measure the "reality" of living - the shared environment in which people live-against earlier work on this issue, which focused on people's happiness and satisfaction with life [Rogerson (1999)]. In livability comparisons, the emphasis has moved from satisfaction with life to conditions of life. "These ranking exercises treat the attributes of a good life as a location to be purchased" [Cobb (2000), p. 9], and have predominantly become 'place based' rather than 'people based'.

Since the QoL index is a weighted index, another issue that needs to be tackled is the weighing scheme. Early efforts to rank cities, e.g., by the Places Rated Almanac, assigned equal weights to all categories. However, people do not accord equal importance to different factors affecting their lives. Table 3 
ranks those factors that people consider important to their lives. Rogerson (1997) used the survey method to assign relative weights in which respondents were asked to rank components of the QoL index according to their priorities. The principal component and hedonic methods can also be used to derive weighing scheme [cited in Slottje (1991)].

Table 3

Items Considered Most Important in People's Lives

\begin{tabular}{cl}
\hline Priority & Item \\
\hline 1 & Relationship with family/relatives \\
2 & Own health \\
3 & Health of close friend/family member \\
4 & Finances/housing/standard of living \\
5 & Relationships with other people \\
6 & Availability of work/ability to work \\
7 & Other (crime, politics, happiness/well-being) \\
8 & Social life/leisure activities \\
9 & Conditions at work/job satisfaction \\
10 & Education \\
11 & Religion/spiritual lore \\
12 & Environment (pollution, rubbish, noise, safety, and cleanliness) \\
\hline Source: Rogerson (1999).
\end{tabular}

Summing up, measuring the diversity of urban centre and urban life as such is fraught with many methodological issues. These include: choice of indicator (objective vs. subjective); dimensions to be included in the construction of the indices; and questions regarding aggregation technique (e.g., weights to be assigned to different factors). Having discussed these, we now turn to major city ranking initiatives being undertaken around the world.

\section{MAJOR CITY RANKING INITIATIVES}

This section discusses in detail the major city ranking initiatives. The list is not exhaustive; rather, the purpose is to shed light on what is being measured and how. These initiatives have been taken up at various levels and involve many stakeholders including development agencies (The UN-HABITAT Habitat Global Urban Indicators Programme (GUIP) and the City Data Book (CDB) Database of the Asian Development Bank (ADB)), national governments (New Zealand QoL Reporting System, Canadian QoL Reporting System, Australian Unity Well-being Index), business consultants (Mercer Human Resource Consulting - Cost-of-living/QoL Surveys, EIU—Worldwide Cost-of-living/QoL Surveys), as well as combination of academia and commercial concerns (Creativity Index). 


\section{UN-Habitat GUIP}

The GUIP is an initiative under the United Nations Human Settlement Program. The first Global Urban Indicator Database (GUID1) was launched in 1996, ${ }^{14}$ and data from 237 cities was collected using 1993 as the reference year. A city development index was derived to rank cities according to their level of development. The Istanbul+5 conference (2001) reviewed the indicators programme and another round of surveys was conducted in 1998. The second Global Urban Indicators Database (GUID2) collected data from 232 cities in 113 countries. Data on a number of indicators (Table 4) were collected from secondary sources based on the latest available information, and converted to US dollars using guidelines provided by the International Monetary Fund (IMF)'s International Statistics Yearbook 1998 [UN-Habitat (n.d.)].

Table 4

\section{UN-HABITAT GUIP List of Indicators}

\begin{tabular}{ll}
\hline Tenure & $\begin{array}{l}\text { Tenure types, evictions, house price and rent-to-income } \\
\text { ratios, land price to income ratios }\end{array}$ \\
Infrastructure & Water, sewerage, electricity, telephone \\
$\begin{array}{c}\text { Health and } \\
\text { Education }\end{array}$ & $\begin{array}{l}\text { Under-five mortality, life expectancy at birth, literacy rate, } \\
\text { combined enrollment }\end{array}$ \\
Water & Water consumption, water prices \\
Waste & Wastewater treated, formal solid waste disposal, formally \\
Management & recycled \\
Population & $\begin{array}{l}\text { Total population (metropolitan area, urban agglomeration, } \\
\text { national urban, national), population growth rates }\end{array}$ \\
Economic and & GDP per capita, city product, household income, informal \\
Workforce & employment, unemployment rate \\
Issues & \\
Transport & Travel time, transport modes to work \\
Safety & Reported crime rates \\
Local & Local government revenue and expenditures \\
Government & \\
\hline Source: UN-Habitat (n.d).
\end{tabular}

${ }^{14}$ Established in 1988 as the Housing Indicator Programme, its scope was later broadened in 1993 to measure sustainable urban development prior to the HABITAT II Conference in 1996. 
In addition, it reports qualitative data on the following indicators:

- housing rights,

- decentralisation,

- urban violence,

- citizens’ participation,

- disaster prevention and mitigation,

- transparency and accountability,

- local environmental plans,

- international cooperation, and

- public-private partnerships.

The City Development Index (CDI) is the average of five subindices. These include city product, infrastructure, waste, health, and education. Each subindex comprises several indicators that are normalised so that their values range between 0 and 1 . Table 5 indicates the formulae used to calculate the CDI. The weighing scheme is derived using principal components analysis.

Table 5

Calculation of CDI by UN-HABITAT GUIP

\begin{tabular}{|c|c|}
\hline Index & Formula \\
\hline Infrastructure & $\begin{array}{l}25 x \text { water connections }+25 \times \text { sewerage }+25 x \text { electricity }+ \\
25 x \text { telephone }\end{array}$ \\
\hline Waste & Wastewater treated x $50+$ formal solid waste disposal x 50 \\
\hline Health & $\begin{array}{l}\text { (Life expectancy - 25) x 50/60 + (32 - child mortality) } x \\
50 / 31.92\end{array}$ \\
\hline Education & Literacy x 25 + combined enrolment x 25 \\
\hline Product & $(\log$ city product -4.61$) \times 100 / 5.99$ \\
\hline CDI & $\begin{array}{l}\text { (Infrastructure index }+ \text { waste index }+ \text { education index }+ \\
\text { health index }+ \text { city product index) } / 5\end{array}$ \\
\hline
\end{tabular}

\section{ADB CDB Database}

This ADB initiative was launched in 1999 under regional technical assistance for the development of a CDB for the Asian and Pacific Region, to cater to the need for improved data, indicators, and benchmarking in managing fast-growing cities in this region. The objective of this exercise was to "establish a policy oriented urban indicators database for research, policy formulation, monitoring of the development impact of the interventions in the urban sector, comparison of performance between cities, and improving the efficiency of 
urban service delivery" [ADB (2001), p. x]. Data on 140 indicators was collected from 16 cities. ${ }^{15}$ These indicators were grouped into 13 main divisions:

- population, migration, and urbanisation;

- municipal services;

- income disparity, unemployment, and poverty;

- urban environment;

- health and education;

- urban transport;

- urban productivity and competitiveness;

- cultural factors;

- technology and connectivity;

- local government finance;

- housing;

- urban governance and management; and

- urban land.

This database is used to construct three indexes: (i) the City Development Index (CDI), (ii) the congestion index, and (iii) the connectivity index.

The CDI is a city-level version of the HDI. It combines the city product subindex with the health, education, infrastructure, and waste management subindices. These subindices are constructed by normalising their component variables, which assigns them values between 0 and 1 , and then taking a weighted average. The weights are derived using principal component analysis. The congestion index is composed of travel time, residential density, and city population, and provides a measure of crowding. Finally, the connectivity index measures a city's connectedness with the outside world, and is calculated based on information on internet connections, corporations, tourism, and flights.

Table 6 gives the formulae for the three indices. The weighing scheme is derived using principal component analysis.

\section{Mercer Human Resource Consulting}

Mercer Human Resource Consulting is the consulting business of Marsh and McLennan Companies, with offices in 39 countries and over 15000 employees. It conducts an annual Quality of Living Survey and twice a year Cost-of-living Survey with the governments and multinational companies as their target audience. The purpose is to provide reliable information to these

\footnotetext{
${ }^{15}$ The participating cities include: Bangalore (India), Bishkek (Kyrgyz Republic), Cebu, Mandaluyong, Naga (Philippines), Colombo (Sri Lanka), Dhaka (Bangladesh), Hanoi (Viet Nam), Hohhot, Honk Kong (China), Kathmandu (Nepal), Lahore (Pakistan), Medan (Indonesia), Melbourne (Australia), Phnom Penh (Cambodia), Seoul (Republic of Korea), Suva (Fiji Island), and Ulan Bator (Mongolia).
} 
Table 6

Calculation of CDI by $A D B C D B$

\begin{tabular}{|c|c|}
\hline Index & Formula \\
\hline Infrastructure & $\begin{array}{l}25 \mathrm{x} \text { water connections }+25 \mathrm{x} \text { sewerage }+25 \mathrm{x} \text { electricity }+ \\
25 \mathrm{x} \text { telephone }\end{array}$ \\
\hline Waste & Wastewater treated x $50+$ formal solid waste disposal x 50 \\
\hline Health & $\begin{array}{l}\text { (Life expectancy - 25) x 50/60 + (32 - child mortality) x } \\
50 / 31.92\end{array}$ \\
\hline Education & $\begin{array}{l}\text { Literacy x } 25+\text { primary enrollment x } 25+\text { secondary } \\
\text { enrollment x } 25+\text { graduates } / 350 \text { x } 25\end{array}$ \\
\hline Product & $\begin{array}{l}\text { (log city product }-\log 400) \times 30 / 2.71+(\log \text { of residential } \\
\text { density }-1.98) \times 30 / 4.86+40 \times(\log \text { population }-2.78) / 6.7\end{array}$ \\
\hline \multicolumn{2}{|c|}{ City Development (Infrastructure index + waste index + education index + } \\
\hline Congestion & $\begin{array}{l}\text { (log travel time }-2.08) \times 30 / 2.71+(\log \text { of residential } \\
\text { density }-1.98) \times 30 / 4.86+40 \times(\log \text { population-2.78)/6.7 }\end{array}$ \\
\hline Connectivity & $\begin{array}{l}(\log \text { Internet }+0.71 / 6.34)+\log \text { corporations } / 6.7+(\log \\
\text { tourism }-3.42) / 5.75+(\log \text { flights }-4.33) / 5.27-0.07 / 3.3\end{array}$ \\
\hline
\end{tabular}

Source: ADB (2001).

agencies/companies so as to protect the purchasing power of their employees and compensate them for any hardship they might face on their international assignments.

\section{Mercer Human Resource Consulting-Cost-of-living Survey}

Mercer Human Resource Consulting conducts twice a year the Cost-ofliving Survey to measure differences in the cost-of-living that employees of government agencies and multinational companies have to face on their international postings, so as to 'facilitate mobility' and manage 'international assignment costs' for the expatriates. It gathers information about prices of 186 products and services in more than 250 cities in 39 countries. The goods and services constitute a 'standard shopping basket' for the expatriates [Mercer (2006a)]. This information is then grouped into 10 categories:

- food at home,

- domestic services,

- alcohol and tobacco,

- utilities,

- household supplies,

- food away from home,

- health and personal care,

- transportation, 
- clothing and footwear, and

- sports and leisure.

Information is also collected on an additional 25 items to calculate the Accommodation, and the Educational costs tables and Business Travel expenses. Mercer calculates three cost-of-living indices: (i) the reversible mean-to-mean index, (ii) the efficient index, and (iii) the convenience index. The mean-to-mean index compares mean prices between the base city and host city. The efficient index compares the average of low and mid-prices in the base city with mean prices in the host city (for experienced consumers). The convenience index compares the average of low and mid-prices in the base city with high prices in the host city (for inexperienced consumers) [Mercer (2006a)].

\section{Mercer Human Resource Consulting-QoL Survey}

Mercer Quality of Living Survey provides information on the differences in the Quality of Life among cities around the world, with a view to assess hardship allowance for expatriates on international assignments. "Hardship refers to special compensation to expatriates who experience a significant deterioration in living conditions once transferred" [Mercer (2006b)].

This survey collects information on 39 QoL life determinants from 235 cities, using New York City as a base city. This information is then grouped into ten categories:

- consumer goods (availability of food and other daily consumption items);

- economic environment (currency exchange regulations and banking services);

- housing (housing, household appliances, furniture, and maintenance services);

- medical and healthcare (medical supplies and services, infectious diseases, sewage, waste disposal, and air pollution);

- natural environment (climate and natural disasters);

- political and social environment (political stability, crime, and law enforcement);

- public services and transport (electricity, water, public transport, and traffic congestion);

- recreation (restaurants, theatres, cinemas, sports, and leisure);

- school and education (standards of education and availability of schools); and

- sociocultural environment (censorship, limits on personal freedom, etc.). 


\section{Economist Intelligence Unit}

The Economist Intelligence Unit also conducts twice a year the Cost of Living Survey and an annual Quality of Living Survey. The purpose again is to provide a tool to human resources managers and expatriate executives to compare the cost of living and to 'calculate fair compensation policies for relocating employees' in 130 cities around the world. "The purpose of a cost of living allowance is to reimburse employees for excess living costs resulting from a foreign assignment, based on the assumption that an expatriate has a right to live at the assignment site in the same manner and with the same kind of goods and services he would find at home" [EIU (2005a)].

\section{EIU-Worldwide Cost-of-living Survey}

This survey is conducted twice a year: in the first week of March for the June (spring) edition, and in the first week of September for the December (autumn) edition. The spring/autumn editions for the current year are compared with the corresponding editions from the previous year. The survey collects information on 50,000 different prices of about 160 items (products and services) in over 130 cities across 86 countries. Prices are collected from three types of retailers: (i) supermarkets, (ii) medium-priced retailers, and (iii) more expensive specialty shops. They are grouped into 13 categories, ten of which are used to calculate the weighted index, which are given below:

- shopping basket,

- utilities,

- alcohol beverages,

- clothing,

- household supplies,

- domestic help,

- personal care,

- recreation and entertainment,

- tobacco, and

- transportation.

Four other categories-housing rents, international schools, health and sports, and business trip costs-are included in the price survey but not in the index calculation. The cost-of-living index is calculated from this data by using the average price (arithmetic mean) as the base. It is a weighted index and the weights accorded to the ten categories are given in Table 7.

The EIU city report gives two indices: (i) the mean index, which compares average prices in the home city with average prices in a foreign city; and (ii) the high index, which compares average prices in the home city with the highest prices in a foreign city [EIU (2005a)]. 
Table 7

Weights of EIU Cost-of-living Index

\begin{tabular}{lc}
\hline Category & Weight \\
\hline Shopping Basket & 25.0 \\
Alcohol Beverages & 3.5 \\
Household Supplies & 4.5 \\
Personal Care & 4.0 \\
Tobacco & 2.5 \\
Utilities & 6.5 \\
Clothing & 13.0 \\
Domestic Help & 3.5 \\
Recreation and Entertainment & 18.0 \\
Transportation & 19.5 \\
Total & 100 \\
\hline
\end{tabular}

\section{EIU-Worldwide QoL Survey}

This indicator measures the level of hardship in a city. The 2005 survey expands on previous surveys and collects information on 40 components of hardship indicators, which are grouped into five categories. These indicators are ranked on a scale of 1 to 5 , where 1 (at 0 percent) means no hardship and 5 (at 100 percent) means extreme hardship. ${ }^{16}$ The groupings are as follows:

- Stability: prevalence of petty/violent crime, and threat of military conflict, civil unrest/conflict, or terrorism.

- Healthcare: availability and quality of private healthcare, availability and quality of public healthcare, availability of over-the-counter drugs, and general healthcare indicators.

- Culture and environment: climate (humidity/temperature, discomfort to travelers), cultural hardships (corruption, social/religious restrictions, level of censorship, sports, culture), food and drink, and availability of consumer goods and services.

- Education: availability and quality of private education, and general public education indicators.

- Infrastructure: transport (quality of road networks, public transport, and regional and international links); housing (availability of goodquality housing); utilities (quality of energy and water provision, and quality of telecommunication infrastructure).

${ }^{16}$ Individual indicators are given a rating of 1 to 5 . They are then weighed according to the above breakdown and converted into an overall index. 
A combination of quantitative and qualitative data is used to construct the index. It is accompanied by a detailed city report. Indicators are ranked on a scale of 1 to 5 , where 1 means that the QoL is similar and 5 means that it is extremely challenging. The EIU's QoL index is a weighted index, where 0 means that the QoL in the city is exceptional and 1 means that life is harsh [EIU (2005b)]. The weights used in the calculation are given in Table 8 below.

Table 8

\begin{tabular}{lc}
\multicolumn{2}{c}{ Weights of EIU QoL Index } \\
\hline Category & Weight \\
\hline Stability & 25 \\
Healthcare & 20 \\
Culture and environment & 25 \\
Education & 10 \\
Infrastructure & 20 \\
Total & 100 \\
\hline
\end{tabular}

\section{New Zealand QoL Reporting System}

The New Zealand QoL Reporting System was established in 1999. Its aim was to measure the QoL in large urban areas of New Zealand through perception-based surveys. The 2004 round covers 12 cities, providing information on indicators (below) that are used to measure residents' perceptions of different aspects of living and working in large cities:

- health,

- education,

- urban/built environment,

- employment and economy,

- sense of belonging/community cohesion,

- democracy/participation in community affairs,

- community safety,

- demographics, and

- housing.

About 7,800 respondents were interviewed via telephone (500 from each city /district, and 1,500 from outside the sample cities/districts) [Gravitas (2005)].

\section{Canadian QoL Reporting System}

The Canadian QoL Reporting System was developed in 1999 by the Federation of Canadian Municipalities. It provides a QoL index for 20 urban 
municipalities ${ }^{17}$ from indicators that are grouped into six factors:

- local economy,

- fairness and equity,

- natural and built environment,

- basic needs,

- personal goals and aspirations, and

- social inclusion.

The data for this exercise is derived from a larger reporting system (Federation of Canadian Municipalities' QoL Reporting System) that contained hundreds of variables measuring changes in social, economic, and environmental factors. These variables were grouped into 75 indicators [Federation of Canadian Municipalities (2004)].

\section{Australian Unity Well-being Index}

The Australian Unity Well-being Index measures and monitors the subjective well-being of the Australian population. It is based on the perception that QoL is both subjective (how people feel about life) as well as objective (the material conditions in which they live) [Cummins, et al. (2001)].

The information used to construct this index comes from telephone interview with 2,000 respondents. The sample is representative of the national geographical distribution of the country's population. The index incorporates both personal and national perspectives, and assesses people's perception of the following factors:

- life as a whole,

- standard of living,

- health,

- achievements in life,

- personal relationships,

- personal safety,

- community connectedness, and

- future security.

The National Well-being Index measures how satisfied people are with life in Australia. It evaluates people's perception of the following four factors:

- life in Australia,

- economic situation,

- state of the environment, and

- social conditions.

${ }^{17}$ The system started with 16 municipalities in 1999. It was expanded to include four more municipalities by 2004 and covers 40 percent of the population. 


\section{Creativity Index}

This composite index was developed by Richard Florida to measure the creative capabilities of American cities. The creativity index is a combination of four (equally weighted) indices: (i) the talent index, (ii) the high-tech index, (iii) the innovation index, and (iv) the diversity index. The talent index measures the creative class's share of the workforce. The high-tech index is based on the Milken Institute's tech pole index. The innovation index measures patent per capita, and the diversity index measures an area's openness to different kinds of people and ideas.

\section{PAKISTANI CITIES IN THE INTERNATIONAL PERSPECTIVE}

Before making any proposal for the development of a system for measuring and ranking Pakistani cities, we explore efforts that have already been carried out in ranking places in Pakistan. Interestingly, one notes that these ranking exercises take districts as their unit of analysis and do not measure and rank cities. Siddiqui (2007), in testing alternative theories for human development, has ranked districts of Pakistan based on the 'basic need' approach. Jamal, Khan, Toor and Amir (2003) have also ranked districts of Pakistan on the basis of deprivation indices. These indices are based on education, housing quality and congestion, residential housing services and employment sectors and are constructed from Population and Housing Census data of 1998. Pasha, et al. (1998) develop a district ranking system for Pakistan based on economic and social development. The social development indicator includes education, health and water supply. Whereas, the economic development indicators includes income and wealth, agriculture, housing conditions, transport and labor. ${ }^{18}$ Hussain (2003) has also calculated the Human Development Index at the district level for Pakistan, following the same methodology as used in the construction of cross-country HDI. At the level of government, Centre for Research on Poverty Reduction and Income Distribution (CRIPRID), Planning Commission, Government of Pakistan, provides a ranking of districts on the progress of selected millennium development goals (MDG) indicators [Pakistan (2006b)]. Moreover, the Government of Pakistan, since 2004-05, also conducts Pakistan Social and Living Standards Measurement Survey on an annual basis. This survey collects data on education, health and housing, water supply and sanitation and ranks districts on these important indicators [Pakistan (2006a)].

At the city level, UN-Habitat's Global Urban Indicators Programme covers Karachi and Lahore. This programme has calculated a CDI for a sample

\footnotetext{
${ }^{18}$ This is preceded by their earlier work on social development ranking of districts. See Pasha, et al. (1996). Also see Pasha, Mallik, and Jamal (1990), Jamal and Mallik (1988) and Pasha and Hasan (1986).
} 
of 162 countries according to which Lahore scores a value of 61.1-a belowaverage score. The mean value for the CDI for this sample is 64.3 and the median is 68.1. Figure 1 shows the relative position of Lahore vis-à-vis other cities.

Fig. 1. City Development Index

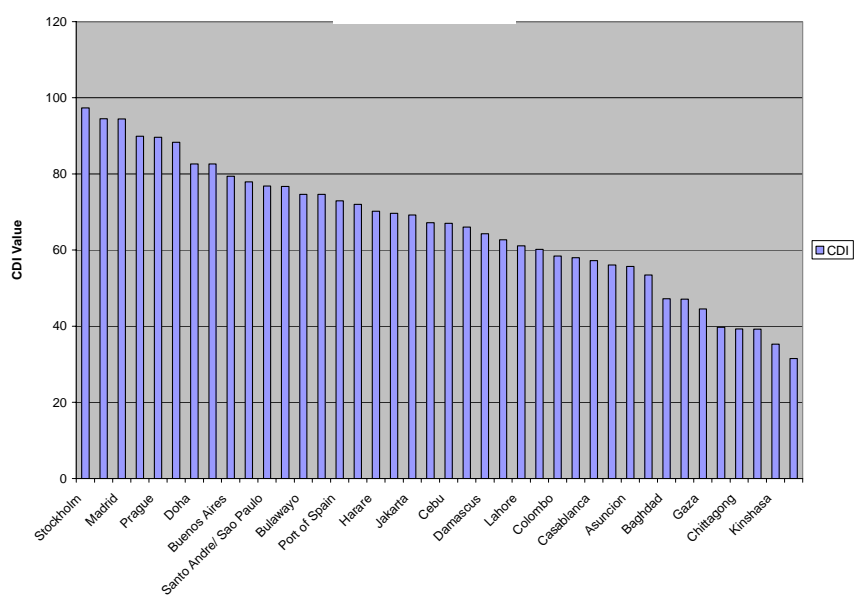

Figure 2 (below) plots CDI values against city ranks—Lahore, ranked at 89 , lies at the lower end of the tail.

Fig. 2. Ranking of World Cities by GUO City Development Index

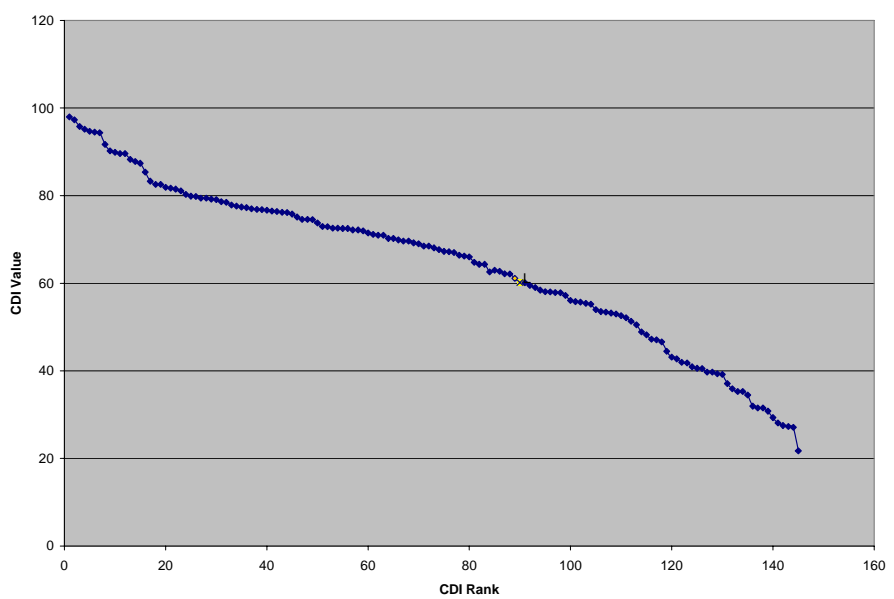


Lahore is also a participating city in ADB's CDB for the Asia and Pacific Region, according to which it falls in the "low-developed city" category, ${ }^{19}$ which ranks low on the connectivity index (24) and high on the congestion index (73.1). Figure 3 plots connectivity index and Figure 4 plots congestion index.

Fig. 3. Connectivity Index

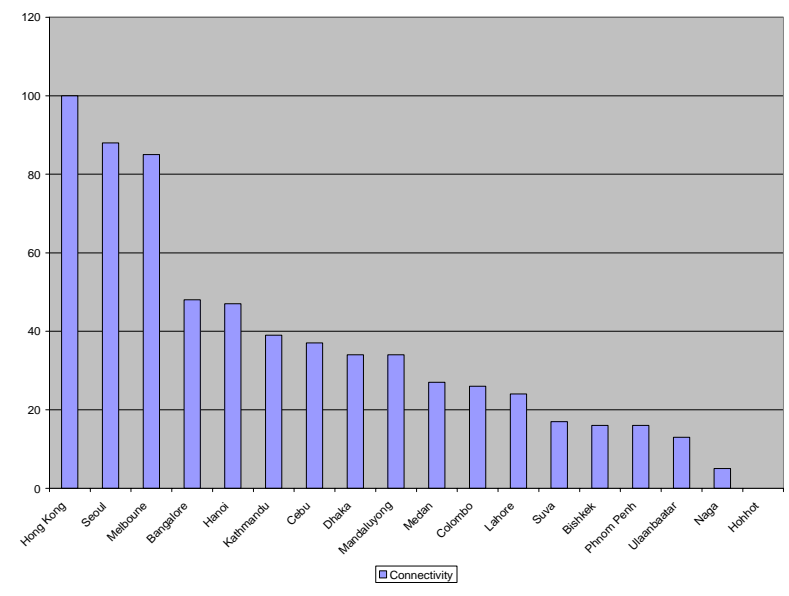

Fig. 4. Congestion Index

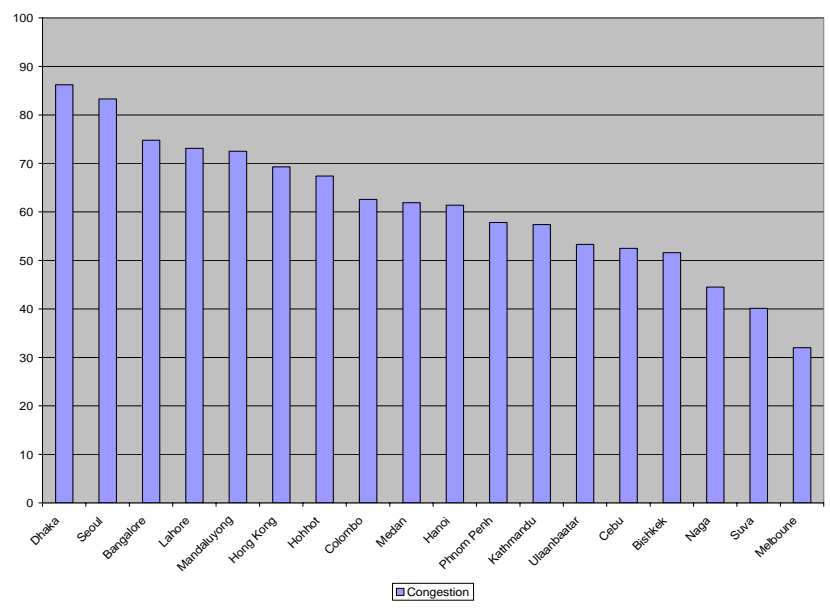

${ }^{19}$ The ADB CDI is similar to the UN-HABITAT's CDI. We therefore do not discuss Lahore's position on this index. 
According to Mercer's yearly cost-of-living index (Table 9), Karachi was ranked at 140 in 2006, with a cost-of-living index of 56.1, having dropped many places from its 2005 rank. It compares well with many other South Asian cities, however, (Dhaka 62.5 and Bangalore 56.4) except for Mumbai, which stands at 68 (cost-of-living index $=79.9$ ).

Table 9

Mercer Cost-of-living Index

\begin{tabular}{|c|c|c|c|c|c|}
\hline \multicolumn{2}{|c|}{ Rankings } & \multirow[b]{2}{*}{ City } & \multirow[b]{2}{*}{ Country } & \multicolumn{2}{|c|}{ Cost-of-living Index } \\
\hline March 2006 & March 2005 & & & March 2006 & March 2005 \\
\hline 68 & 105 & Mumbai & India & 79.9 & 70.8 \\
\hline 131 & 127 & Dhaka & Bangladesh & 62.5 & 62.5 \\
\hline 139 & 141 & Bangalore & India & 56.4 & 51.7 \\
\hline 140 & 136 & Karachi & Pakistan & 56.1 & 56.1 \\
\hline
\end{tabular}

Source: Mercer (2006a).

The EIU's QoL index for 2005 rates life in Karachi as extremely hard, with an index value of 60 percent ( 0 percent means no hardship and 100 percent means extreme hardship, a score above 50 percent means that life is severely restricted due to terrorism, etc.) [EIU (2005b)].

It is evident that only two Pakistani cities (Karachi and Lahore) feature in international/regional comparisons, while other major cities do not appear in the picture.

\section{CONCLUSION AND RECOMMENDATIONS}

Cities are the loci of most human activities-economic, social as well as cultural. With nearly half of the worlds population living in cities, and prospects of an ever increasing share in future, especially in Asia and Africa, cities in these regions face many challenges. More jobs will have to be created for the swarming labour force, urban amenities will also come under added pressure. Further, globalisation of economic activities has made both physical and human capital highly mobile. Especially, people with skill and talent have a preference for areas offering 'good life'. Cities face increasing competition to attract and retain investment and human capital.

In this context, city rankings become important as they provide a tool to gauge the multiple attributes of urban areas and to make inter-temporal or interregional comparisons. However, Pakistan lacks a city ranking system at present. The only notable efforts to measure Pakistani cities-UN-HABITAT's GUIP and ADB's CDB-have limited scope: (i) they are restricted to a maximum of two cities, (ii) their survey exercises are not carried out on a yearly basis, and (iii) they are limited by their own agenda. The GUIP was developed to monitor progress on UN-HABITAT's agenda while ADB's Urban Indicators for Managing Cities scrutinises the development of its urban strategy. 
There is clearly a need to develop a city ranking system for Pakistan. Many issues need to be addressed in designing such a system. Based on our previous discussion we can classify these as: (1) choice of indicator-what do we want to measure? (2) type of indicator-objective vs. subjective; (3) attributes to be measured; and (4) weighing scheme.

Coming to the first question, three main types of indicators were discussed-QoL, cost of living, and city performance. Of these, quality of life studies are most widely used. National governments throughout the world monitor quality of life of its citizens since improving well-being is an important concern for any government. Recently it is also used as a promotional tool in city marketing to attract residents and businesses. We propose that a nationwide QoL monitoring system should be developed for Pakistan. But since QoL refers to individuals only and do not measure city performance, this exercise may be supplemented by a performance-based city ranking system for major cities in Pakistan.

The second issue in QoL monitoring system is about the choice of indicator, i.e., whether to opt for an objective or subjective indicator. Objective indicators (infant mortality, literacy rate, infrastructure, etc.) have many advantages: (i) they are easily defined and measured more precisely; (ii) objectivity also means there is general consensus about the value of what is being measured, e.g., everyone believes that infant mortality is bad and literacy is good and does not rely on individual perception. They can "assess societal qualities that do not rest solely on their influence on subjective well-being, but which are based on widely shared values" [Diener and Suh (1997), p. 194]. Moreover, objective indicators are easier to compare across time and geographical space [Costanza, Farley, and Templet (2002)]. Their weakness lies in the fact that they are chosen in an ad hoc manner, depending on the subjective opinion of the researcher selecting them. Diener (1995) has proposed a valuebased index of QoL that uses variables that reflect a society's common values. The greatest limitation of objective indicators is that they might not reflect people's experience of well-being [cited in Costanza, Farley and Templet (2002)].

Subjective indicators, on the other hand, measure individual perceptions of well-being based on a respondent's judgment rather than that of policymakers or researchers. However, they suffer from the weakness that similar life circumstances might be viewed differently by different respondents, making it difficult to take individual responses as valid and accurate. Such indicators might not reflect the objective quality of community life as much as temperaments and personal relationships [Diener and Suh (1997)].

Which factor should be given more importance is also controversial. How should weights be assigned to different factors? In the initial years of city rankings (the late 1970s and early 1980s), the practice was to weigh each factor equally. This practice was discontinued since people are apt to differentiate 
between the importance's of different factors. Currently, statistical procedures like principal component method and the hedonic approach are used to assign weights. Rogerson (1997) has worked around this problem by using a survey method in which respondents were asked to order different attributes according to the priority they attached to each [cited in Rogerson (1999)].

To estimate QoL in Pakistani cities, this paper recommends that objective indicators be supplemented by subjective ones, since both capture different dimensions of well-being. Objective indicators measure "facts" (such as housing and infrastructure) while subjective indicators focus on "softer" issues such as the perceived adequacy of dwelling [Veenhoven (2004)]. The first type measure attributes at the city level and the latter at a personal level. This is in line with Rogerson (1999) and endorsed by Diener and Suh (1997) and Veenhoven (2004). "What is good for the people cannot be determined without taking their views into account" [Diener and Suh (1997), p. 207]. An objective indicator should include attributes around which consensus has emerged. These include measures of economic well-being, housing, health and education, work opportunities, infrastructure (public services), transport, land, environment, public safety, recreation, cultural activities, and urban governance. The exercise should be done on an annual basis. This should be supplemented by an annual residents' perception survey about their quality of life. With respect to the performance-based city rating system for Pakistan, Table A1 (Appendix) lists factors used in the construction of City Development Index (CDI) for Lahore and Karachi, which can serve as a useful starting point for developing such a system. The next important issue in this exercise concerns data. City level data on most indicators is not readily available. While previous studies [Jamal, Khan, Toor, and Amir (2003) and Pasha, et al. (1998), etc.] had used census data for their analysis, it is not a suitable source if conditions/performance of cities and quality of life is to be monitored on an annual basis. The study proposes to develop a databank for the indicators discussed above. Initially a survey team could collect data from the city governments and other government departments working at the city level, which should be updated annually. 
Appendix

\section{Table A1}

\section{Dimensions of CDI as Measured by ADB}

\begin{tabular}{|c|c|}
\hline Demographic & City Population \\
\hline Health and Education & $\begin{array}{l}\text { Person per Hospital Bed/Doctor/Nurse } \\
\text { School Enrollment Rates } \\
\text { Tertiary Graduates } \\
\text { School Children per Classroom }\end{array}$ \\
\hline Urban Productivity & $\begin{array}{l}\text { City Product } \\
\text { Employment by Industry } \\
\text { Unemployment } \\
\text { Household Expenditure }\end{array}$ \\
\hline Housing & $\begin{array}{l}\text { House Price to Income Ratio } \\
\text { House Cost to Income Ratio }\end{array}$ \\
\hline Infrastructure & $\begin{array}{l}\text { Water Connections } \\
\text { Investment/ expenditure per capita } \\
\text { Electricity Connections } \\
\text { Investment/ expenditure per capita } \\
\text { Solid Waste Collection Household Number } \\
\text { Investment/ expenditure per capita }\end{array}$ \\
\hline Urban Environment & $\begin{array}{l}\text { Solid Waste Generation } \\
\text { Sewage Disposal } \\
\text { Waste Water treated } \\
\text { Energy Usage } \\
\text { Noise Complaint } \\
\text { Pollution } \\
\text { Solid Waste Collection }\end{array}$ \\
\hline Urban Transport & $\begin{array}{l}\text { Travel Time } \\
\text { Expenditure on Roads } \\
\text { Road Congestion } \\
\text { Automobile Ownership }\end{array}$ \\
\hline New Technology & $\begin{array}{l}\text { Telephone Connections } \\
\text { Internet Connections }\end{array}$ \\
\hline Culture & $\begin{array}{l}\text { News Papers/Media } \\
\text { Cultural Events/Attendance } \\
\text { Museums/Attendance }\end{array}$ \\
\hline Public Safety & Crimes \\
\hline Urban Land & $\begin{array}{l}\text { Vacant Government Land } \\
\text { Vacant Land with Planning Permission } \\
\text { Public Open Space } \\
\text { Prime Commercial Land Price } \\
\text { Prime Rental Cost }\end{array}$ \\
\hline Urban Governance & $\begin{array}{l}\text { Functions of Local Government } \\
\text { Annual Plans } \\
\text { Voters Participation }\end{array}$ \\
\hline
\end{tabular}

Source: ADB (2001). 


\section{REFERENCES}

Asian Development Bank (2001) Urban Indicators for Managing Cities: Cities Data Book. M. S. Westfall and V. A. de Villa. (eds.). Manila: ADB.

Biagi, B., D. Lambiri, and V. Royuela (2006) Quality of Life in the Economic and Urban Economics Literature. Centre for North South Economic Research, University of Cagliari and Sassari, Sardina. (Working Paper No. 10.). <www.crenos.it/working/pdf/06-10.pdf>

Blomquist, G. C., M. C. Berger, and J. P. Hoehn (1988) New Estimates of Quality of Life in Urban Areas. American Economic Review 41, 169-186.

Booysen, F. (2002) An Overview and Evaluation of Composite Indices of Development. Social Indicators Research 59, 115-151.

Bramston, P., G. Pretty, and H. Chipuer (2002) Unravelling Subjective Quality of Life: An Investigation of Individual and Community Determinants. Social Indicators Research 59, 261-274.

Clark, D., J. Kahn, and H. Ofek (1988) City Size, Quality of Life, and the Urbanisation Deflator of the GNP: 1910-1984. Southern Economic Journal 54: January, 701-714.

Cobb, C. W. (2000) Measurement Tools and the Quality of Life. Redefining Progress. San Francisco. USA. <www.rprogress.org>

Costanza, R., J. Farley, and P. Templet (2002) Quality of Life and the Distribution of Wealth and Resources. In R. Constanza and S. E. Jorgensen (eds.) Understanding and Solving Environmental Problems in the 21st Century. Elsevier Science Ltd.

Crafts, N. F. R. (1997) Some Dimensions of the 'Quality of Life' During the British Industrial Revolution. Economic History Review, L (4): 617-639.

Cummins, R. A., R. Eckersley, J. Pallant, J. Van Vugt, J. Shelley, M. Pusey, and R. Misajon (2001) Australian Unity Well-Being Index. Survey 1: Report 1. Australian Unity Limited and Australian Centre on Quality of Life, Deakin University. <http://acqol.deakin.edu.au/index_wellbeing/index.htm>

Diener, E., and E. Suh (1997) Measuring Quality of Life: Economic, Social, and Subjective Indicators. Social Indicators Research 40, 189-216.

Duranton, G., and D. Puga (2001) Nursery Cities: Urban Diversity, Process Innovation and the Life Cycle of Products. American Economic Review 91: December, 1454-1477.

Economist Intelligence Unit (EIU) (2005a) World-wide Cost of Living Survey. $<$ http://wcol.eiu.com>

Economist Intelligence Unit (EIU) (2005b) World-wide QoL Survey. Available at: http://wqol.eiu.com

Fahey, T., B. Nolan, and C. T. Whelan (2003) Monitoring Quality of Life in Europe. European Foundation for the Improvement of Living and Working Conditions. $<$ http://www.eurofound.eu.int/pubdocs/2002/108/en/1/ef02108en.pdf> 
Federation of Canadian Municipalities (2004) The FCM Quality of Life Reporting System. Highlights Report 2004. Quality of Life in Canadian Municipalities. <http://www.fcm.ca/english/qol/reports.html>

Florida, R. (2002) The Economic Geography of Talent. Annals of the Association of American Geographers 92: 4, 743-755.

Glaeser, E. L., H. D. Kallal, J. A. Scheinkman, and A. Shleifer (1992) Growth in Cities. Journal of Political Economy 100: December, 1126-1152.

Glaeser, E. L., J. Kolko, and A. Saiz (2001) Consumer City. Journal of Economic Geography 1, 27-50.

Gravitas Research and Strategy Limited (2005) Quality of Life in New Zealand's Six Largest Cities—Residents' Survey. <www.bigcities.govt.nz/pdf2004/ Quality_of_Life_2004_full_report.pdf>

Hall, P. (1995) Towards a General Urban Theory. In J. Brocthie, M. Batty, E. Blakely (eds.) Cities in Competition. Melbourne: Longman.

Ham, S. A., S. Levin, A. I. Zlot, R. R. Andrews, and R. Miles (2004) Ranking of Cities According to Public Health Criteria: Pitfalls and Opportunities. American Journal of Public Health 94:4.

Haque, N. U., and D. Nayab (eds.) (2007) Cities-Engines of Growth. Islamabad: Pakistan Institute of Development Economics.

Hasan, Lubna (2007) On Ranking Cities: Issues and Options, in Nadeem Ul Haque and Durre-e-Nayab (eds.) Cities_Engines of Growth. Islamabad: Pakistan Institute of Development Economics.

Hussain, A. (2003) Poverty, Growth and Governance. Pakistan National Human Development Report. United Nations Development Programme.

Jamal, H., A. J. Khan, I. A. Toor and N. Amir (2003) Mapping the Spatial Deprivation of Pakistan. The Pakistan Development Review 42: Summer, 91111.

Jamal, H., and S. Malik (1988) Shifting Patterns in Development Rank Ordering: A Case Study of the Districts of Sindh Province. The Pakistan Development Review 27: Summer, 159-182.

Jensen, O. B. (2005) Branding the Contemporary City-Urban Branding as Regional Growth Agenda? Plenary paper for Regional Studies Association Conference 'Regional Growth Agendas'. Aalborg, 28th to 31st May, 2005. Aalborg, United Kingdom.

Langlois, A. and D. E. Anderson (2002) Resolving the Quality of Life/Wellbeing Puzzle: Toward a New Model. Canadian Journal of Regional Sciences 25: Autumn, 510-512.

Lanteigne, C. A. (2005) Quality of Life in Cities. Unpublished Master's thesis. The University of New Brunswick.

Lijn, N. V. D. (n.d) Measuring Well-being with Composite Indicators, HDI PQLI, BWI for 133 Countries for 1975, 1980, 1985, 1988, 1992. 
Luger, M. I. (1996) Quality of Life Differences and Urban and Regional Outcomes: A Review. Housing Policy Debate 7: 4, 749-771.

McCrea, R., T. Shyy and R. Stimson (2006) What is the strength of the Link Between Objective and Subjective Indicators of Urban Quality? Applied Research in Quality of Life 1, 79-96.

Mercer Human Resource Consulting (2006a) Cost of Living Report 2006. $<$ http://www.mercerhr.com>

Mercer Human Resource Consulting (2006b) Quality of Living Survey 2006. $<$ http://www.mercerhr.com>

Naude, W., S. Rossouw, and W. Krugell (2006) The Quality of Metropolitan City Life in South Africa. Work Well Research Unit for People, Policy and Performance, and School of Economics, Risk-Management and International Trade, North-West University, Potchefstroom. South Africa.

Nayab, Durre (2007) The City in Human Life, in Nadeem Ul Haque and Durre Nayab (eds.) Cities-Engines of Growth. Islamabad: Pakistan Institute of Development Economics.

Nussbaum, M., and A. K. Sen (1993) The Quality of Life. Oxford. Clarendon Press.

Overman, H. G., and A. J. Venables (2005) Cities in the Developing World. Centre for Economic Performance. London School of Economics and Politcal Science, London. (CEP Discussion Paper No. 695.)

Pakistan, Government of (2006a) Pakistan Social and Living Standards Measurement Survey (2004-2005). Federal Bureau of Statistics, Islamabad.

Pakistan, Government of (2006b) Pakistan Millennium Development Goals Report 2006. Centre for Research on Poverty Reduction and Income Distribution (CRIPRID), Planning Commission, Government of Pakistan, Islamabad.

Pasha, A. G., H. Pasha, R. Ghaus, A. R. Khan, N. Ahmed, and R. Khan (1996) Social Development Ranking of Districts of Pakistan. Social Policy and Development Centre, Karachi. (SPDC Research Report No. 10.)

Pasha, A. G., H. Pasha, R. Ghaus, A. R. Khan, N. Ahmed, and R. Khan (1998) Social and Economic Development. Social Policy and Development Centre, Karachi. (SPDC Research Report No. 18.)

Pasha, A. H., and Tariq Hasan (1986) Development Ranking of Districts of Pakistan. In Ijaz Nabi (ed.) The Quality of Life in Pakistan: Studies in Social Sector Economics. Lahore: Vanguard.

Pasha, H. A., S. Malik, and H. Jamal (1990) The Changing Profile of Regional Development in Pakistan. Pakistan Journal of Applied Economics 9.

Rahman, T., R. C. Mittelhammer, and P. Wandschneider (2003) Measuring the Quality of Life Across Countries: A Sensitivity Analysis of Well-being Indices. Paper prepared for presentation at WIDER International Conference on Inequality, Poverty and Human Well-being, May 30-31, 2003. Helsinki, Finland.

Rogerson, R. J. (1999) Quality of Life and City Competitiveness. Urban Studies 36 (5-6): 969-985. 
Shackman, G., Y. L. Liu, and X. Wang (2005) Measuring Quality of Life Using Free and Public Domain Data. Social Research Update 4. <www.soc.surrey. ac.ul/sru>

Shapiro, J. M. (2006) Smart Cities: Quality of Life, Productivity, and the Growth Effects of Human Capital. Review of Economics and Statistics 88: 2.

Siddiqui, R. (2007) The Role of Household Income and Public Provision of Social Services in Satisfaction of Basic Needs in Pakistan: A Cross-districts Analysis. Paper presented at the 22nd Annual General Meeting of the Paksitan Society of Development Economics. Lahore, December, 2006.

Slottje, D. (1991) Measuring the Quality of Life across Countries. The Review of Economics and Statistics 73: Nov. 684-693.

Sveikauskas, L. (1975) The Productivity of Cities. Quarterly Journal of Economics 89: August, 393-413.

Turksever, A. N. E., and G. Atalik (2001) Possibilities and Limitations for the Measurement of the Quality of Life in Urban Areas. Social Indicators Research 53, 163-187.

United Nations Center for Human Settlement (UNCHS) (2001) The State of the World's Cities. UNCHS.

United Nations Center for Human Settlement (UNCHS) (2007) The State of the World's Cities. UNCHS.

United Nations Human Settlement Programme (UN-Habitat) (n.d) Global Urabn Indicators Database, Version 2. Global Urban Observatory. United Nations Human Settlement Programme (UN-Habitat). <www.unhabitat.org/>

Veenhoven, R. (2004) Subjective Measures of Well-being. United Nations University. World Institute for Development Policy Research. (Discussion Paper No. 2004-07.)

Wish, N. B. (1986) Are We Really Measuring the QoL? Well-being Has Subjective Dimensions, as well as Objective Ones. American Journal of Economics and Sociology 45: January, 93-99. 